\title{
DISCLAIMER
}

This report was preparod as an accounl of work sponsored by an agency of the United States Government. Neither 1'se United States Government nor any agency thereof, nor any of their employes. makes any warraniy, express or implied, or assumes any legal liability or responsibility for the accuracy, completeness, or usefulness of any information, apparatus, product, or process disclosed, or represents that its use would not infringe privately owned rights. Reference herein to any specific commercial product, process, or service by trade name, trademark. manufacturer, of otherwese does not necessarily constitute or imply its endorsemem, recommendation, or favoring by the United Siates Government of any agency theroof. The views and opinions of authors expressed herejn do not necessarily state or refiect those of the United States Government or any agency thereof

\section{Petrologic and Geochemical Characterization of the Bullfrog Member of the Crater Flat Tuff: Outcrop Samples Used in Waste Package Experiments}

\author{
K. G. Knauss

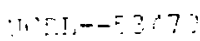 \\ Manuscripi date: September 1983
}

\section{LAWRENCE LIVERMORE NATIONAL LAHORATORY University of California - Livermore, California $\cdot 94550$}




\section{Contents}

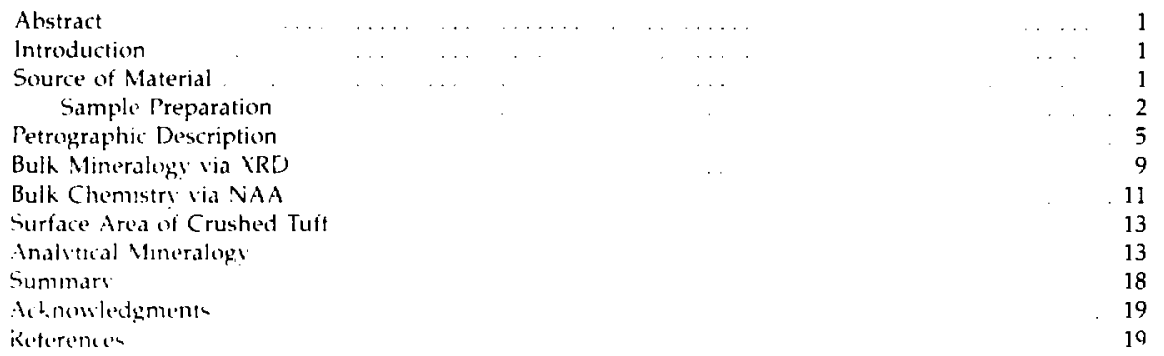




\title{
Petrologic and Geochemical Characterization of the Bullfrog Member of the Crater Flat Tuff: Outcrop Samples Used in Waste Package Experiments
}

\begin{abstract}
In support of the Waste Package Task within the Nevada Nuclear Waste Storage Investigation (NNWSI), experiments on hydrothermal rock/water interaction, corrosion, thermomechanics, and geochemical modeling calcuiations are being conducted. All of these activitess require characterization of the initial bulk composition, mineralogy, and individual phase geochemistry of the potential repository host rock. This report summarias the characterization dome on samples of the Bullfrog Member of the Crater Flat Tuff (Tefb) used for Mante Pachage experimental programs.
\end{abstract}

\section{Introduction}

L mel late los? ane at the fent stratigraphic

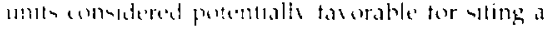

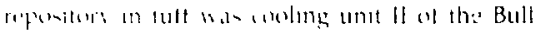

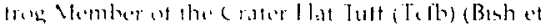

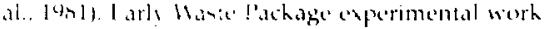
unced Tifb: than, it wan necessary to acquire large quatilien of material huitable for the testing program. Since moterial from core taken from luca Mountain was not adablable in sufficient quantity to supply this need, sutcrop sanples of Tcflo were udected a provide material for this purpose.

To understand the hydrothermal interaction between roch and water in the wiste package (mviromnent, the mineralogic and geochemical character of the tutf must he well known. A variety of tehniquen sas employed to tharacterize thes matertal. wansmited and rebleded light opte

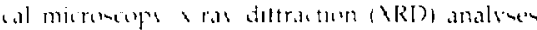

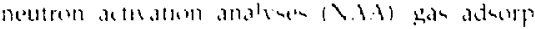

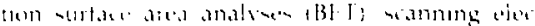

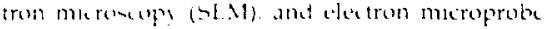
analses (ENP) using both semquantitative enargy dinperase - pectrometrs (EDS) and quantita. tive wavelongth dispersive apectrometry (WDS).

This report summarsen the results of this characterization of Toth material used in all Waste Pachage experiments in the varions subtasks that requiled tulf to be present for conditioning water (e.f., studies on canister corrosion, backfill, and waste form) or a hnowledge of the geochemical nature of the tuff tor modeling (e.g. genchenical or thermal mosteling).

\section{Source of Material}

Based on a correlation of corelogs, geophysial logs, nimer 'ogy, and physical properties of core from holes 1 1, G-2, UE25a-1, and UE25b-1, the proposed repository horizon within the Tofo was defined as an interval -340 to $2545 \mathrm{ft}$ referenced to hole G-1. The petrologic and geochemical characteristics of this interval in several locations throughout the repository block are described in previous reports (Heiken and Bevier, 1979: Sykes et al., 1979; Bish et al., 1981; Caportuscio et al., 1982; Broxton et al., 1982; Scott and Castellanos, 1982).
New data from exploratory drilling, mapping. and petrographic studies in the Bare MountainCrater Flat area (Orkild, 1983: Carr. 1982) have suggested the source of the Crater Flat Tuffs to be two caideras in the Crater Flar wrea (not the Sleeping Butte caldera, as previously believed, Byers et al., 1976). The Tram Member was erupted from the northernmost of these calderas, while the Bullfrog and overlying Prow Pass Mombers were erupted from the southernmost caldera. Although prorly exposed partial sections of Tcth are shown in areas with existing map coverage, the outcrops 
were not suitalole for precise location within the section However. appoximately 8-1/2 miles NW if l.athrop Mells (Nevada Coordinates N705,400' and $1.53 x$ situly an excellent section of $\mathrm{Tcfb}$ is expixed aleng an arroxes on the southwest spur of rema Vowntam

lhe enturep or lesated on the presently un

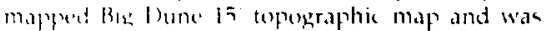

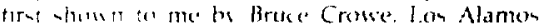

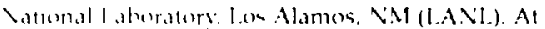
the lis ation :he Tifh secturn everlies a bedded. reworked tutt pomibly contasning fragments of the Cirstare camvon Nember of the Belted Range

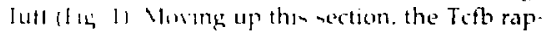
dall progrenas from a nomwelded bate into a moderatels atedeped vitrophyre (lig. 2). The

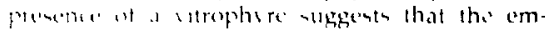

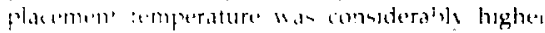

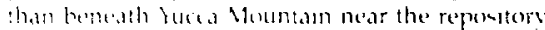

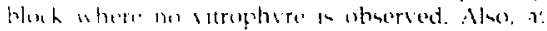
the lex atson the unt in sereral hundred feet thete.

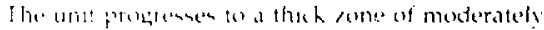
wolded dentrifued Gightly vapor phase altered core (Fig. 3). The top of the unit is nonwelded, pumiceous, and intensely vapor-phase altered. Tlie TcF is overlain by a breccia consisting of Tifb related material indicating relative proximity in the Bullfrog caldera; the breccia owes its origin to caldera collapse (Fig. 4).

At the site selected for sampling (Fig. 5), large block of material were remeved, labeied, and shepped w i.awrence l.nermore Natwonal Laborators Livermore. CA (I.L.NI) for further pretreat. mont. In some cases, tho large blocks were sent directly to other inventigators with no pretreattnent. This was true for David C. Coles, Pacitic Northwest laboratories, Richland, WA and James

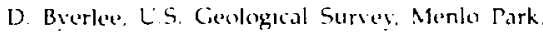
(A) (LSS).

\section{Sample Preparation}

For all work done at 1 I. N1. the large blacks (1) Teth were first trinmed with a large rock naw to remobe weathened material (if any) alorig joinis

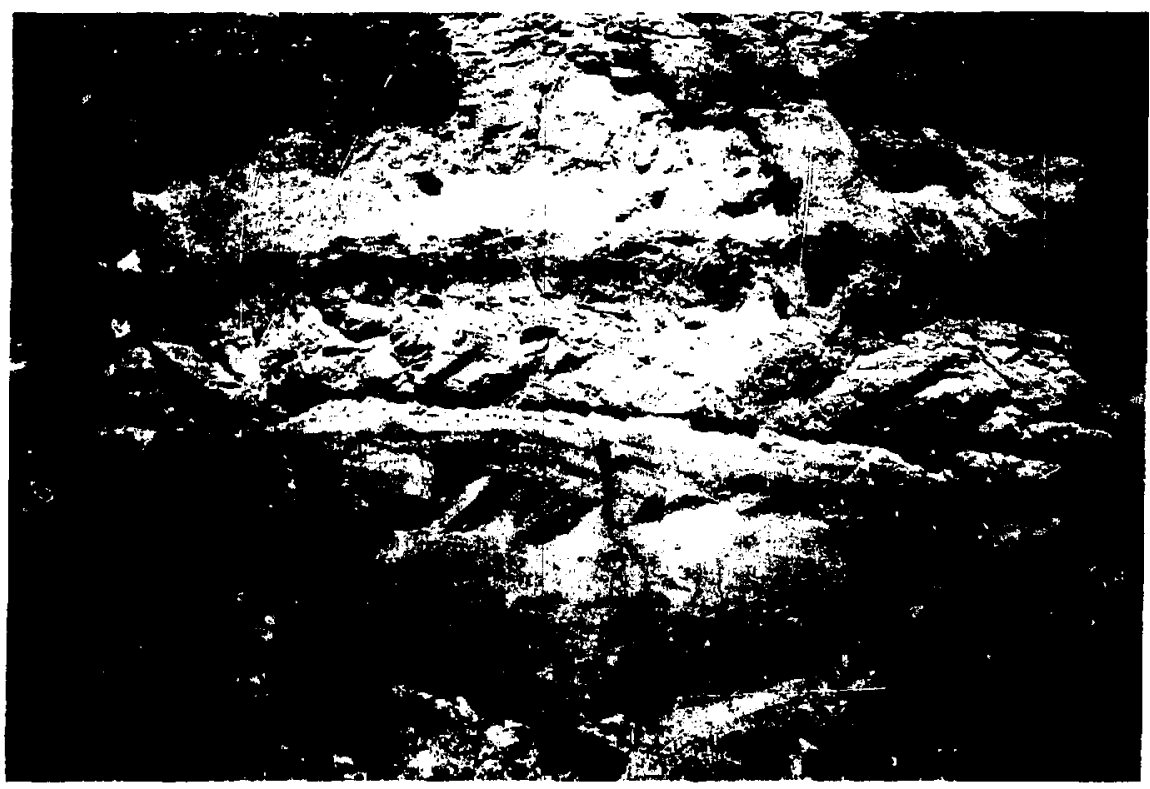

Figure 1. Base of Bullfrog Member overlying a bedded, reworked tuff. 


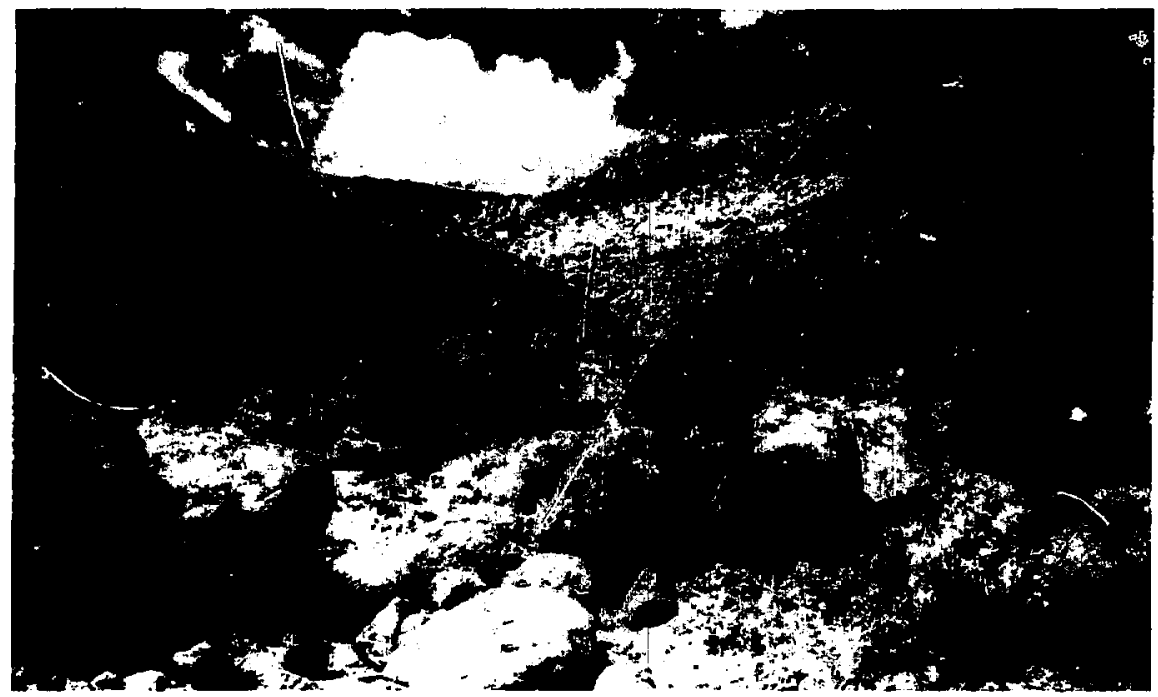

Figure 2. View up the section from below the vitrophyre within the Bullfrog Member. Darker material forming the ledge in the center of the photo is the vitrophyre.

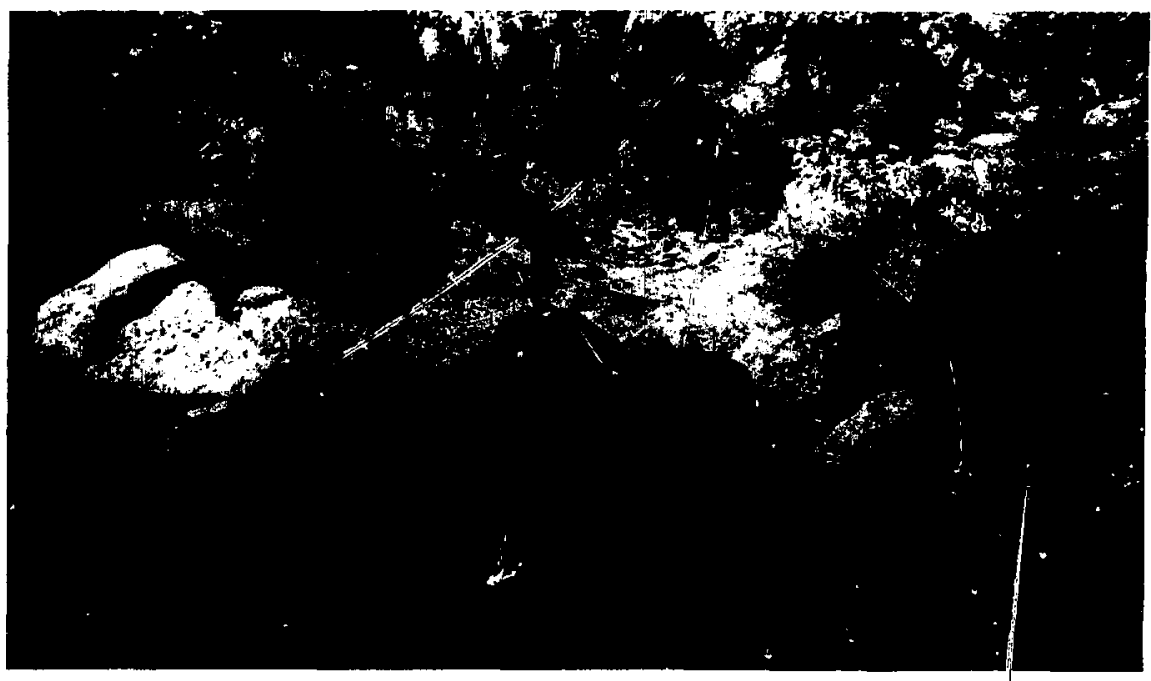

Figure 3. Thick zone of moderately welded, devitrified, slightly vapor-phase alteled Bullfrog Member overlying the vitrophyre. The unit dips to the southeast (right) and is well jointed. Samples were collected from this zone for the Waste Package experimental work. 


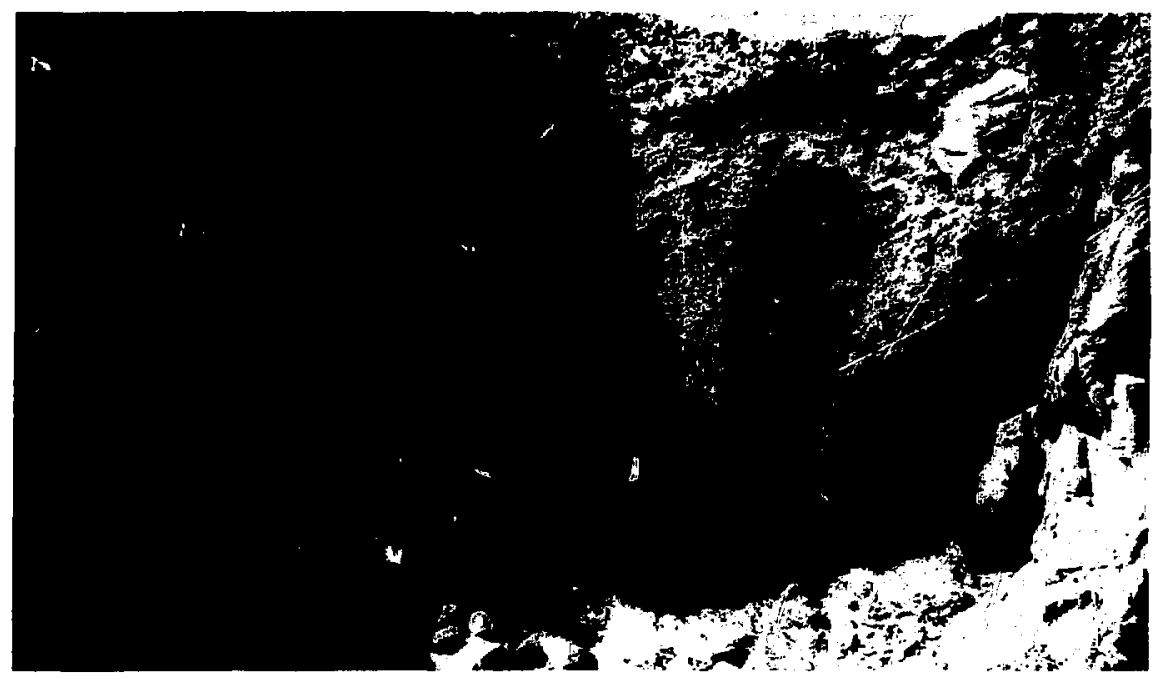

Figure 4. The Bullfrog Member is overlain by a breccia consisting of Bullfrog related material, indicating the relative proximity to the Bullfrog caldera since the breccia owes its existence to caldera collapse. Note the large size of material incorporated in the breccia.

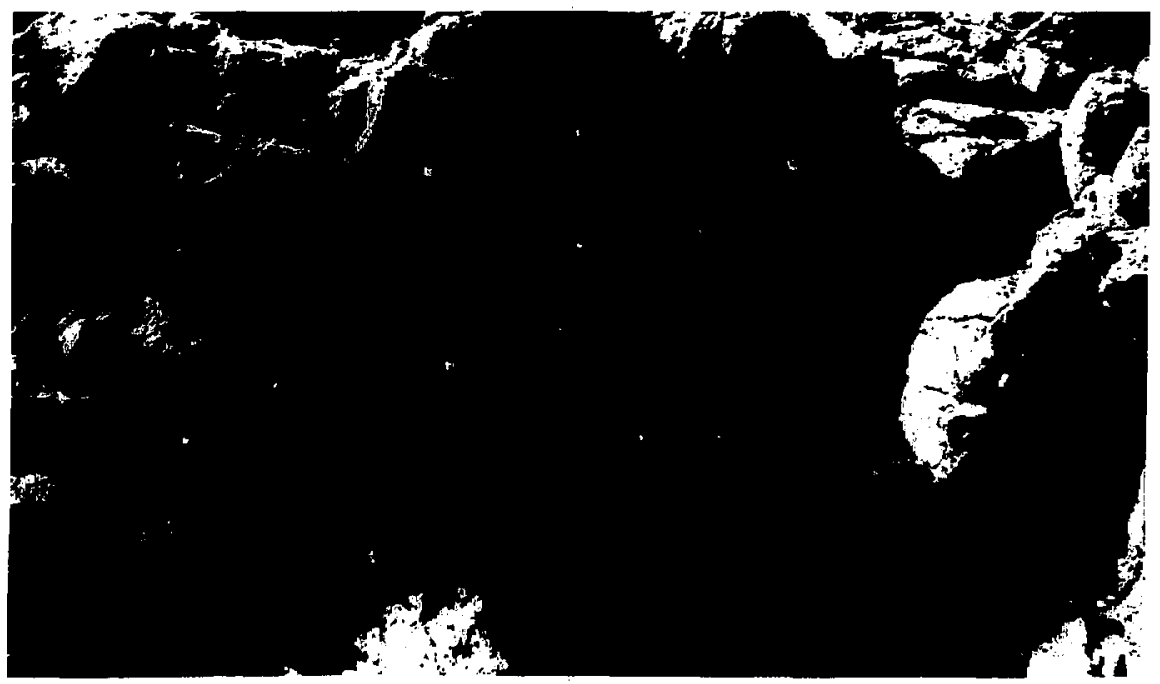

Figure 5. Close-up view of material sampled for Waste Package experimental work. Note the fractured nature of the tuff and the well-developed joint sets. 
and fractures. These trimmed blocks were then either cored or slabbed in preparation for crushing. A thin section from a sample of the slabbed mato rial was used for this characterization. The slabbed material was then crushed to $\mathrm{mm}$ size with a jaw crusher with alumina plates and then pulverized with a Spex mill with a tungsten carbide vessel and ball for Batch $A$ or alumina plates for Tcfb and Batch B. The Batch A and B material used for NAA characterization was sieved to

140 mesh. The XRD sainple was prepared by further pulverizing the $T \mathrm{cfb}$ samples ( -140 mesh) to -325 mesh with a Spex mill. Analytical conditions used during each characterization procedure are described in the appropriate section.

\section{Petrographic Description}

Detailed descriptions of the petrography of the Tcfb have been provided by several reports cited in the Introduction. A point count was not made using the thin section prepared here; rather, the general characteristics and approximate modes were noted for comparison with these previous descriptions.

Observations in transmitted light with a Leitz Orthoplan petrographic microscope show the rock to be a partially to moderately welded, devitrified, partially vapor-phase altered ash flow tuff. The vitric componenti display a variety of textural fealures. Some sharde are quite distinct, yellowhrown to red hrown in colur against a light tan to dark brown groundmass. The shards, which are frequently aligned and draped around phenocrysts, usually have an axiolitic texture and are completely replaced by very fine grained devitrification products. No glass was observed. Pumice ranged from nearly undeformed to flattenec. Some pumice fragments contain spherulites near borders and throughout their centers. Many pumice have red-brown border regions that later EMP analyses will show to be iron rich. Some pumice display a nearly granophyric texture of tightly packed devitrification products. The vitric textures would suggest both primary devitrification and vapor phase alteration followed to some degree by a diagenetic recrystallization. Figures $6-8$ show

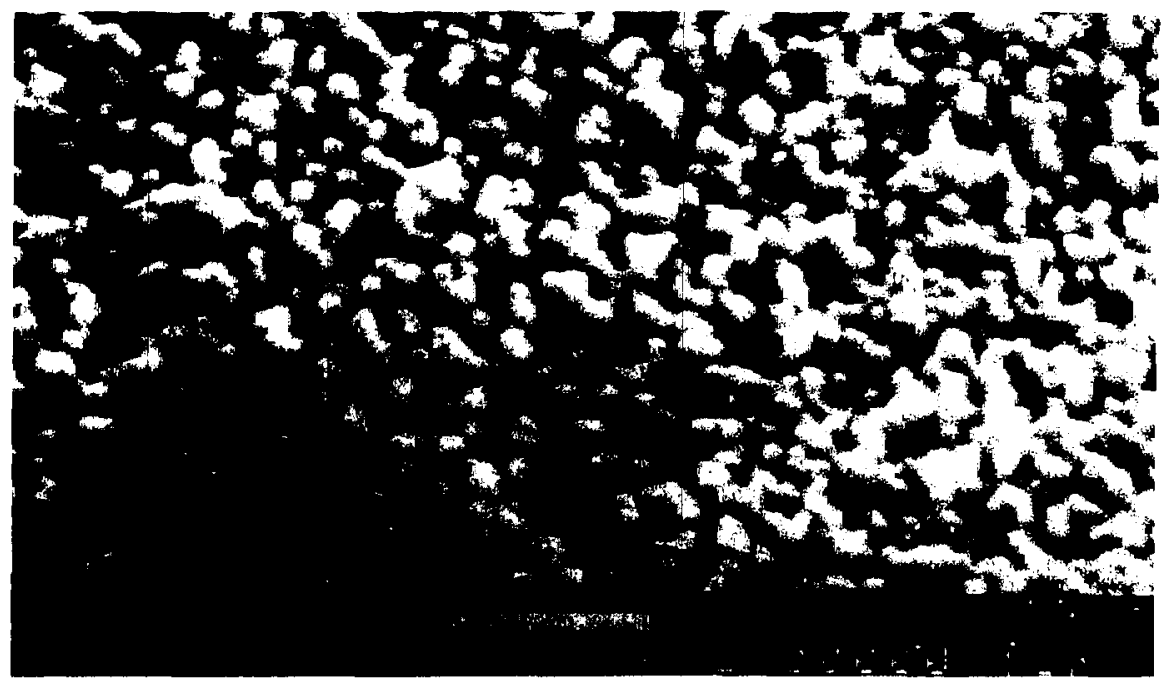

Figure 6. Backscattered electron image of a fractured surface of Bullfrog Member tuff. This material can vary compositionally from quartz to alkali feldspar on a sibmicron scale. 


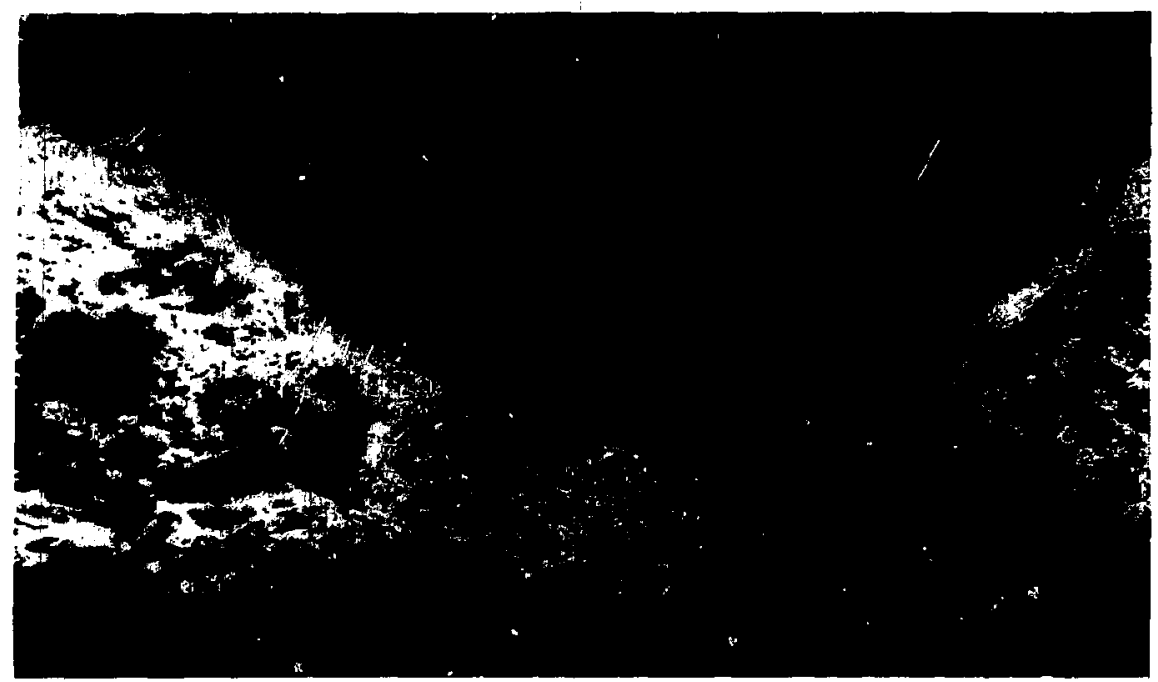

Figure 7. Backscattered electron image of vapor-phase deposited material, primarily alkali feldspar, within a vug.

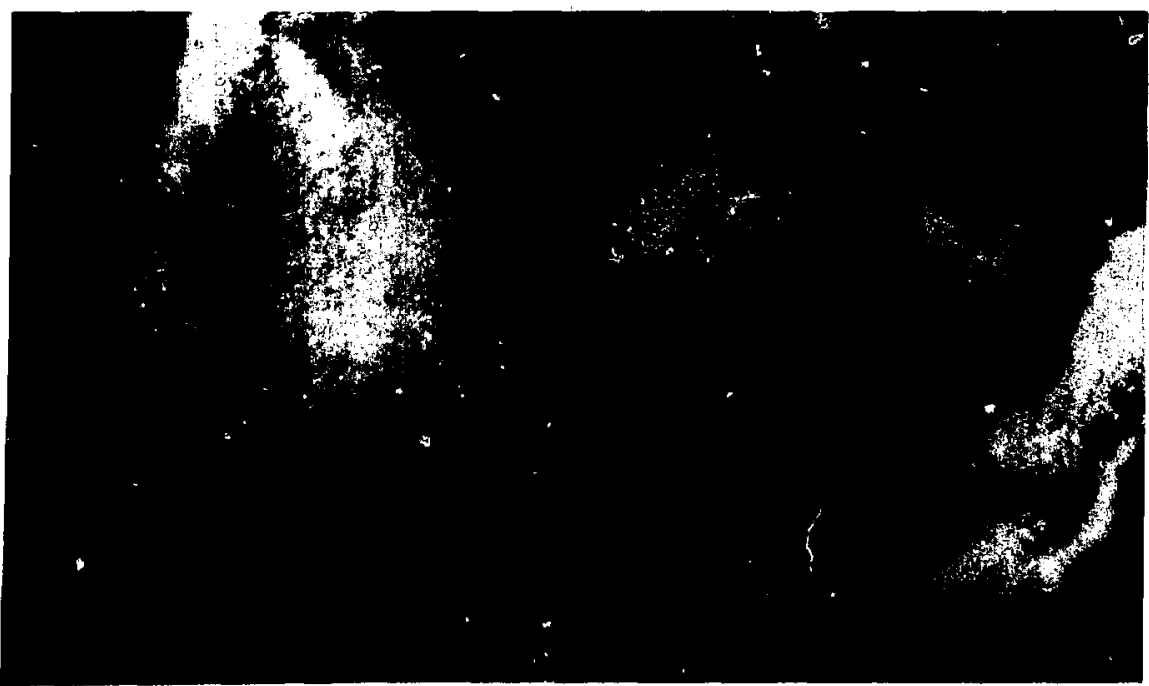

Figure 8. Backscattered electron image of fine-grained quartz and alkali feldspar within a vug. 
the extremely fine-grained nature of these devitrification and vapor-phase products. Both fine granular and fibrous devitrification products consisting of intergrown silica and $\mathrm{K}$-feldspar are shown.

The vitric components comprise about 85$90 \%$ of the rock. The phenocrysts making up the remainder of the rock consist of subequal amounts of sanidine and plagioclase, less quartz, minor biotite, minor magnetite, rare ilmenite and hornblende, and trace zircon and apatite, and no zeolites. Sume comments regarding the appearance of the phenocrysts are warranted. The quartz are large and wormy-resorbed and embayed (Fig. 9). The sanidine and plagioclase are also large but are not resorbed, for the most part. The tiotite (Fig. 10) and hornblende (Fig. 11) are relatively fresh looking, although the edges of biotite are sometimes blackened. This differs fromi most descriptions of these mafic phases in Tcfb beneath Yucca Mountain, with the exception of G-1. These observations (and field evidence based on an absence of zeolites in the nonwelded materials in this section) suggest that at this locality the Tcfb has never been below the static water level.

The rock is relatively porous and contains fractures either open or filled with silica or hematite. As will be shown in a subsequent report (Knauss, 1983), the specific surface area of core wafers used in hydrothermal experiments is nearly as high as that of crushed tuff, attesting to the high interconnected porosity.

Based strictly on a cursory petrographic analy sis, the interval sampled at the Tcfb outcrop appears to correspond to about the $2400 \mathrm{ft}$ level in G-1. Although no cooling break was observed at this locality in the Tcfb section, the presence of a developed vitrophyre suggests we are in a position equivalent to the most densely welded material within the so-called BF-II unit (Bish et al.. 1981). The abundance and size of phenocrysts and the vitric component textures observed here match most descriptions between about 2.320 and $2420 \mathrm{ft}$ relative to $\mathrm{G}-1$.

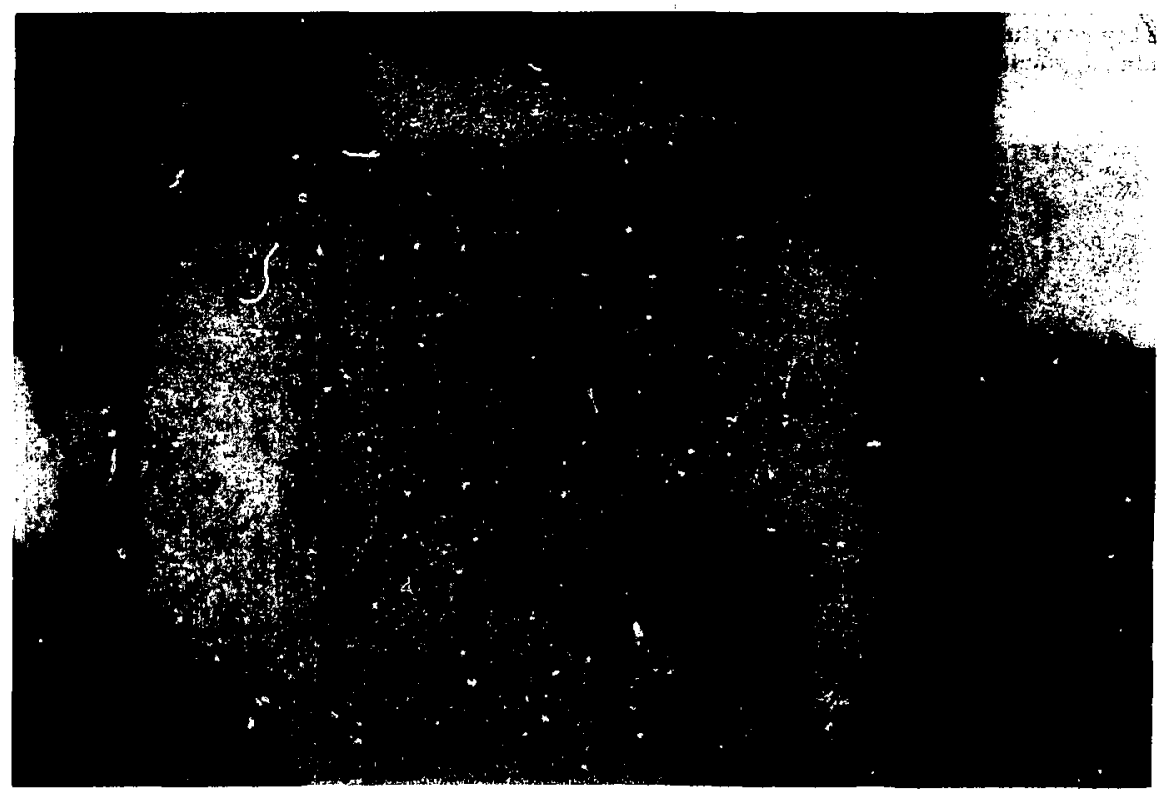

Figure 9. Large wormy-resorbed and embayed quartz phenocrysts are common within the Bullfrog Member. The photomicrograph is spanning approximately $1.5 \mathrm{~mm}$ in the longest dimension. 


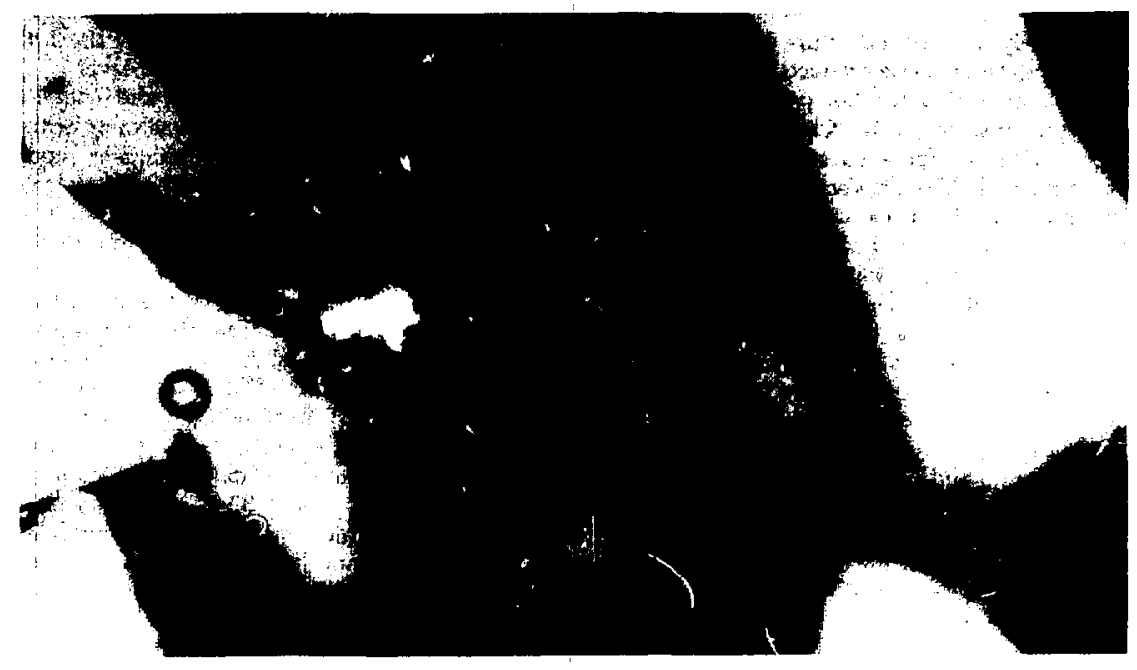

Figure 10. The biotite phenocryst in this Bullfrog Memker section is fairly fresh looking in the central zone from which samplos were collected. The edges may be somewhat blackened, however. They contain numerous included phases such as zircon and apatite. The photomicrograph is spanning approximately $1.5 \mathrm{~mm}$ in the longest dimension.

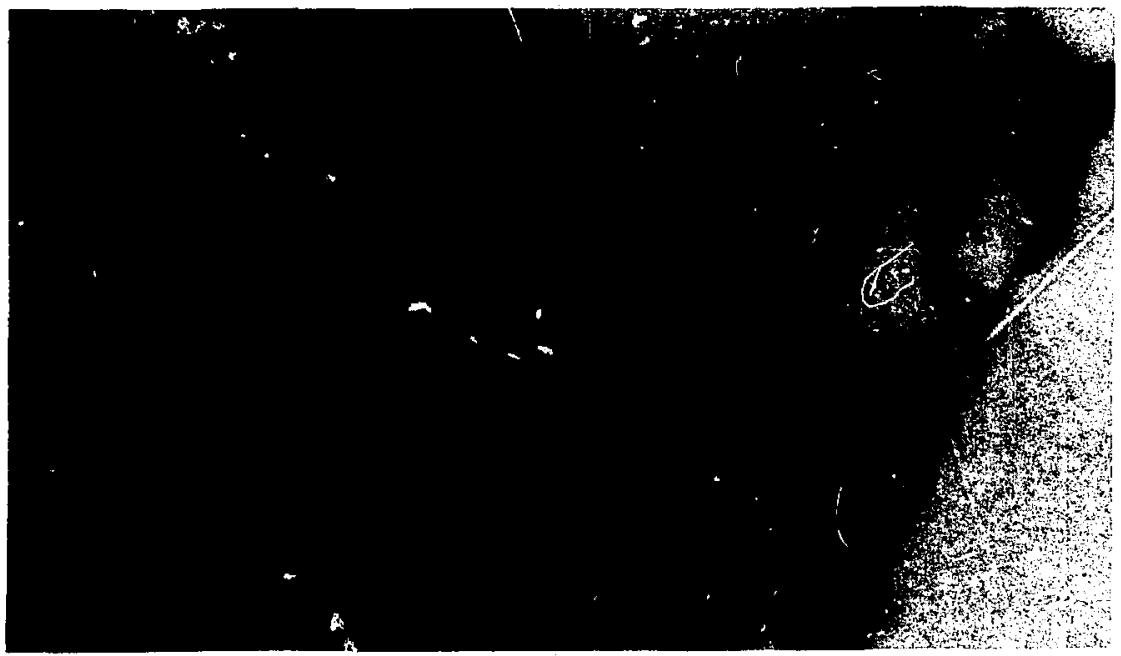

5.mpse 11. The hornblende phenocryst is a much less common mafic than biotite and is a relatively therety. The photomicrograph is spanning approximately $1.5 \mathrm{~mm}$ in the longest dimension. 


\section{Bulk Mineralogy via XRD}

In order to characterize the bulk mineralogy of $\mathrm{Tcfb}$, three sampl of material (Batch $A$, Batch B, and a separate h.nd sample) were analyzed by XRD. The sample powders were run or an automated powde: diffractometer from $2^{\circ}$ to at least $40^{\circ} 2 \theta$ using $\mathrm{Cu}-\mathrm{K}_{u}$ radiation and computerized data recording. The spectra were then analyzed by computer for peak ide atification and calculation of d-spacing, relative intensity, and peak area. This sistem is present!y being cal:brated with standards to allow determination of phose proportions (semi-quantitative analysis). The data for these samples recorded on diskette can be so analyzed at a future date

The XRD spectra recorded were essentially identical. Figure 12 shows the Batch B spectra. Table 1 lists the derived praks. Phases present in amounts easily detectable include alkali feldspar, quar": a-cristobalite, muscovite/illite, and amphi- bole. Notably absent are peaks for tridymite or any of the zeolites encountered at Yuad Mountain. The broad glass peak enteried about a d-spacing of $4 A$ is also absent. Althuugh not identified as a dis.nnct peosk, there in a bulgo on the shoulder of the $x$-ray beam peak at low angle ahove the background inferred by drawing a smonth curve. This bulge ocurs in the general vicinity of montmorillonite and mas corre-pernet to the tan to red-brow'n materlal. which rim- the pumice fragments and is disseminaled throughout the matrix. An effor: $x$ as made to confirm or tony the presence of clays using SEN. luge exponed by cutting core wafers were examin. at, and, as lig. 1.3 show's, ome clay-like phases were present. The'e' phases were very rare, howeser, and mont clas in the Tefb is disenminated thror, hout the matrix (rimming pumice tragments and harde) ur lining fractures.

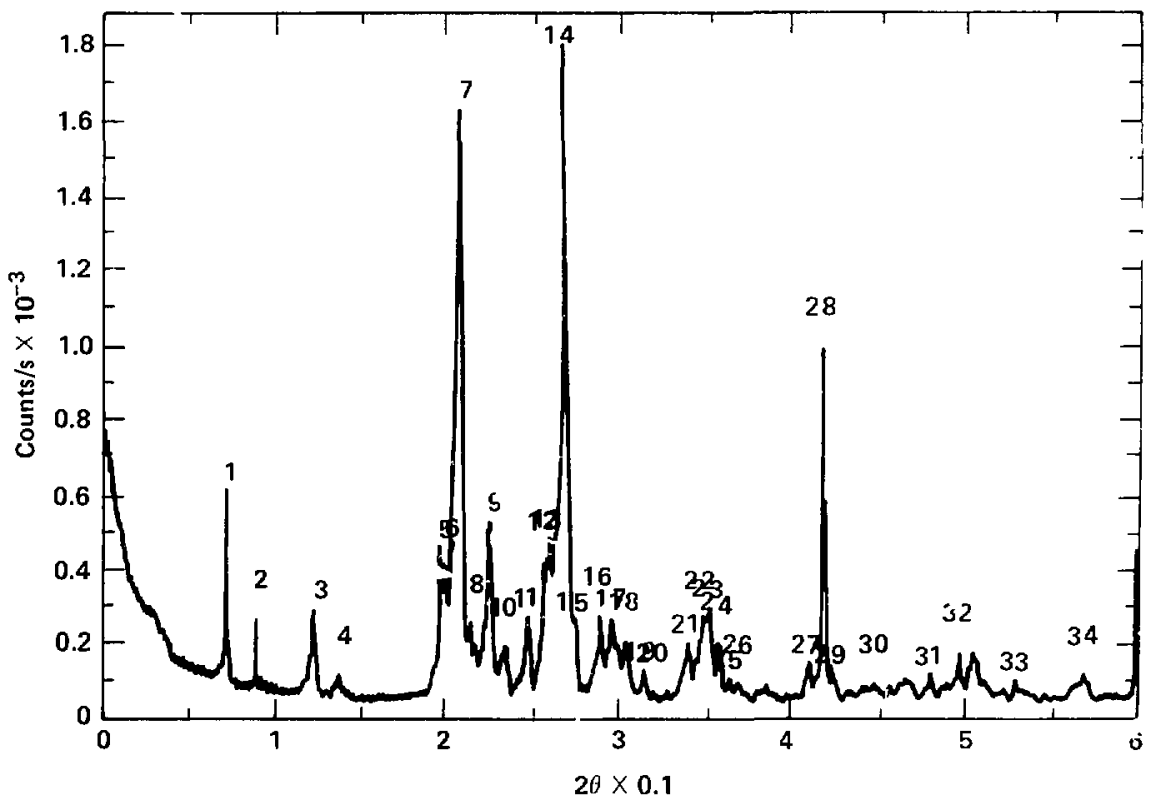

Figure 12. X-ray diffraction spectra of Bullfrog Member used in Waste Package experimental work. The spectra were collected using an automated powder diffractometer and computerized data reduction system. Semi-quantitative analysis of phase proport, ins may be made using this systein. The presence of minor smeclite is indicated by the bulge in the smoothly decreasing curve of scattered $x$ rays from the beam. 
Table 1. X-ray diffraction peaks identified by computer in the Bullfrog Member tuff used in Waste Package experimental work. Phases present include alkali feldspar, quartz, alpha cristobalite, muscovite/allite, and amphibole. Notably absent are peaks for tridymite, zeolite, and glass.

\begin{tabular}{|c|c|c|c|c|}
\hline Peak \# & D-space & Height & Area & Width \\
\hline $\mathbf{1}$ & 9.9938 & 33.8 & 21.9 & 0.242 \\
\hline 2 & 8.4342 & 15.1 & 7.5 & 0.187 \\
\hline 3 & 6.4292 & 16.3 & 12.3 & 0.283 \\
\hline 4 & 5.8390 & 6.7 & 6.1 & 0.342 \\
\hline 5 & 4.2595 & 25.7 & 19.4 & 0.284 \\
\hline 6 & 4.2028 & 23.2 & 11.5 & 0.186 \\
\hline 7 & 4.0511 & 90.0 & 100.0 & 0.216 \\
\hline g & 3.9310 & 14.5 & 9.7 & 0.250 \\
\hline 9 & 3.7664 & 29.3 & 32.5 & 0.415 \\
\hline 10 & 3.6096 & 10.8 & 9.7 & 0.338 \\
\hline 11 & 3.4499 & 15.1 & 13.3 & 0.332 \\
\hline 12 & 3.3335 & 23.8 & 15.4 & 0.242 \\
\hline 13 & 3.2994 & 27.4 & 18.7 & $0.25 \%$ \\
\hline 14 & 3.2155 & 100.0 & 78.4 & 0.294 \\
\hline 15 & 3.1398 & 15.2 & 11.0 & 0.270 \\
\hline $1 \mathbf{b}$ & 2.9877 & 15.4 & 16.5 & 0.401 \\
\hline 17 & 2.9228 & 15.0 & 13.7 & 0.342 \\
\hline 18 & 2.8500 & 11.5 & 8.2 & 0.267 \\
\hline 19 & 2.7642 & 7.2 & 6.2 & 0.319 \\
\hline 20 & 2.7152 & 4.0 & 3.7 & 0.351 \\
\hline 21 & 2.5729 & 11.2 & 7.5 & 0.251 \\
\hline 22 & 2.5198 & 15.0 & 13.3 & 0.331 \\
\hline 23 & 2.4953 & 16.7 & 12.0 & 0.270 \\
\hline 24 & 2.4585 & 11.5 & 8.4 & 0.273 \\
\hline 25 & 2.4149 & 6.3 & 5.7 & 0.343 \\
\hline 26 & 2.3803 & 5.5 & 7.7 & 0.523 \\
\hline 27 & 2.1671 & 8.1 & 8.6 & 0.398 \\
\hline 28 & 2.1303 & 54.9 & 31.1 & 0.212 \\
\hline 29 & 2.1035 & 7.8 & 5.1 & 0.246 \\
\hline 30 & 1.9976 & 5.3 & 6.3 & 0.442 \\
\hline 31 & 1.8761 & 6.7 & 6.0 & 0.338 \\
\hline 32 & 1.8185 & 10.0 & 10.5 & 0.394 \\
\hline .33 & 1.7191 & 5.7 & 5.0 & 0.325 \\
\hline 34 & 1.6101 & 6.4 & 5.8 & 0.339 \\
\hline
\end{tabular}




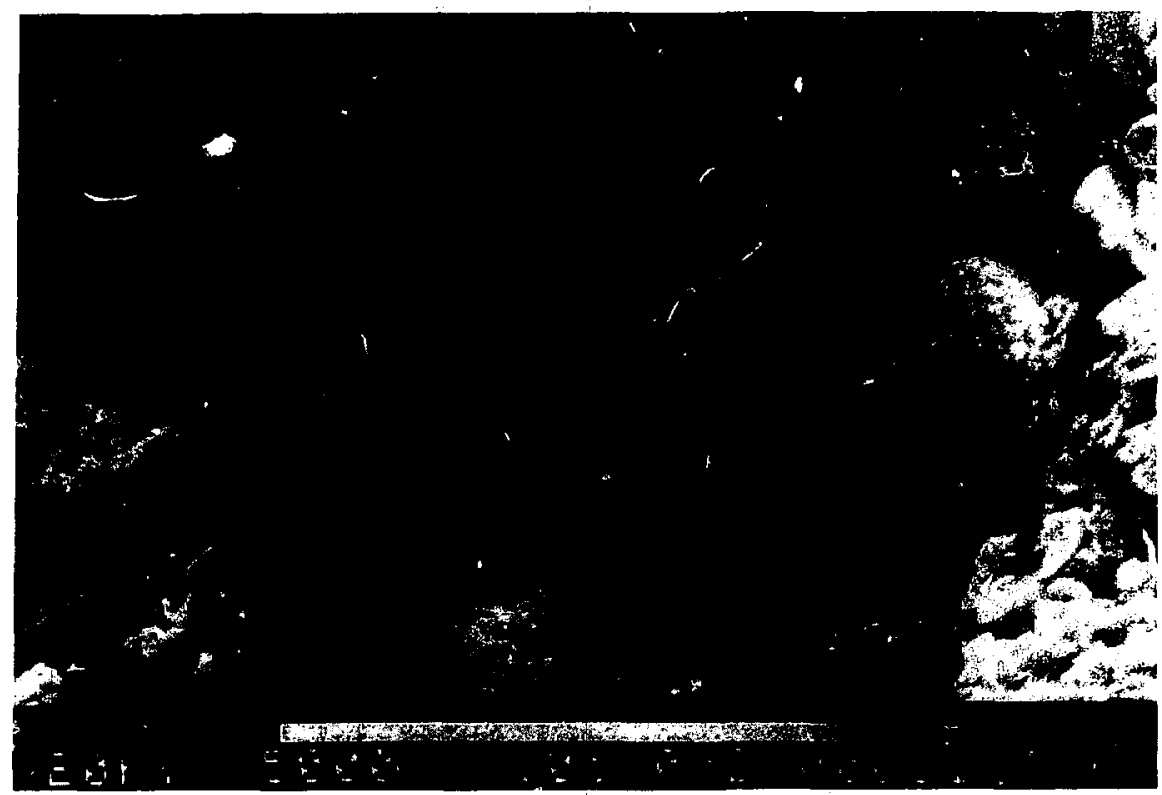

Figure 13. Backscattered electron image of clay-like phase within a vug.

\section{Bulk Chemistry via NAA}

Samples from both Batch $A$ and $B$ were analyzed by NAA for a suite of elements. Approxiniately $200 \mathrm{mg}$ of -140 -mesh material was mixed with an equal amount of Avicel binder and pelletized. The samples were irradiated for $72 \mathrm{~min}$ at a flux of $1.9 \times 10^{13} \mathrm{n} / \mathrm{cm}^{2}$.sec. After cooling times of $4 \mathrm{~d}, 21 \mathrm{~d}$, and $40 \mathrm{~d}$, the samples were counted for periods of $8000 \mathrm{~s}, 20,000 \mathrm{~s}$, and $20,000 \mathrm{~s}$, respectively, with an automated $\mathrm{Ge}$ (Li) gamma spectrometer. Nuclide identification and quantification were done by the GAMANAL code, activity data were converted to composition by NADAC, and the results of multiple count data for each element were combined by the MERGE code. Although not used in calculating sample concentrations (because GAMANAL works with absolute activity), each irradiation and count con- tains an appropriate USGS stanciard rock as a check standard.

Table 2 summarizes the data obtained for the two Tcfb samples analyzed. As can be readily seen, Batch A material has been contaminated by the tungsten carbide vessels. It contains anomalous values for $\mathrm{Cr}, \mathrm{Co}, \mathrm{Ni}$, and $\mathrm{W}$. Fortunately, only a few of the first rock/water interaction experiments were done with Batch A material. These were repeated at a later date with Batch $B$ material. Batch A remained useful for all thermomechanical experiments. The data for the two analyses agree reasonably well and give some feeling for the upproximate sample variability one might expect to encounter in closely spaced samples. 
Table 2. Results for neutron activation analysis of two samples of Bullfrog Member tuff. The Batch A material was prepared in a tungsten carbide Spex mil! and found to contain traces of $\mathrm{Cr}, \mathrm{Co}, \mathrm{Ni}$, and $\mathrm{W}$ not present in the tuff. Batch $B$ is the material used in all rock/water interaction studies with the exception of the very first (preliminary) experiment.

\begin{tabular}{|c|c|c|}
\hline $\begin{array}{c}\text { Element } \\
\text { (ppm) }\end{array}$ & Tcfb-A $\mathbf{A}^{\mathbf{3}}$ & Tcfb-B $B^{b}$ \\
\hline $\mathrm{Na}\left(10^{4}\right)$ & $3.453 \pm 0.059$ & $3.025=0.078$ \\
\hline $\mathrm{K}\left(10^{4}\right)$ & $4.859 \pm 0.379$ & $3.799 \pm 0.274$ \\
\hline $\mathrm{Ca}\left(10^{4}\right)$ & $n d^{c}$ & $\pi d^{\varepsilon}$ \\
\hline $\mathrm{Fe}\left(10^{4}\right)$ & $1.01 s \pm 0.017$ & $1.097 \pm 0.012$ \\
\hline $\mathrm{Sc}$ & $1.226 \pm 0.012$ & $1.294 \pm 0.016$ \\
\hline $\mathrm{Cr}$ & $60.54 \div 0.81$ & $n d^{x}$ \\
\hline Co & $2.887 \pm 0.167$ & $0.537 \pm 0.033$ \\
\hline $\mathrm{Ni}$ & $34.90 \pm 4.68$ & $\mathbf{n d}^{\mathrm{E}}$ \\
\hline $\mathrm{Zn}$ & $38.36 \pm 8.69$ & $73.78 \pm 3.37$ \\
\hline As & $5.883 \pm 0.906$ & $7.578 \pm 1.197$ \\
\hline $\mathrm{Rb}$ & $97.84 \pm 4.93$ & $150.5 \pm 2.2$ \\
\hline $\mathrm{Sr}$ & $127.8 \pm 19.5$ & $259.9 \pm 23.0$ \\
\hline $\mathrm{Zr}$ & $255.7 \pm 45.3$ & $247.4 \pm 35.1$ \\
\hline Alo & nd $^{s}$ & $45.63 \pm 7.68$ \\
\hline $\mathrm{Sb}$ & $0.404 \pm 0.055$ & $0.484=0.047$ \\
\hline $\mathrm{C}_{5}$ & $3.007 \pm 0.115$ & $2.903 \pm 0.078$ \\
\hline $\mathbf{B a}$ & $330.9 \pm 43.5$ & $6692 \pm 16.89$ \\
\hline La & $80.31 \pm 1.28$ & $70 . / \mathrm{i} \pm 0.62$ \\
\hline $\mathrm{Ce}$ & $105.3=0.9$ & $142.5 \div 1.84$ \\
\hline Nd & $45.28+19.41$ & $45.25+4.32$ \\
\hline $\mathrm{Sm}$ & $7.289=0.267$ & $7.695=0.194$ \\
\hline Eu & $0.293 \pm \mathbf{0 . 0 4 2}$ & $0.739 \pm 0.019$ \\
\hline Gd & $91.82 \pm 25.34$ & $8.223 \pm 2.952$ \\
\hline $\mathrm{Tb}$ & $0.576 \div 0.065$ & $0.826=0.019$ \\
\hline$Y b$ & $3.271 \pm 0.146$ & $3.743 \pm 0.083$ \\
\hline Lu & $0.570 \pm \mathbf{0 . 0 3 0}$ & $0.601=0.020$ \\
\hline $\mathrm{Ht}$ & $5.012=0.139$ & $7.361 \pm 0.113$ \\
\hline $\mathrm{Ta}$ & $1.972=0.088$ & $1.561 \pm 0.034$ \\
\hline$w$ & $75.05 \pm 3.80$ & nd \\
\hline $\mathrm{Au}$ & $0.0071=0.0066$ & nd $d^{c}$ \\
\hline Th & $15.94 \pm 0.31$ & $20.98 \pm 0.19$ \\
\hline $\mathrm{U}$ & $2.495+0.353$ & $4.438 \pm 0.257$ \\
\hline
\end{tabular}

"Pulverized in a tungsten carbide Spex Mill.

b Pulverized in a high-purity alumina, flat-plate grinder.

sot detectable. 


\section{Surface Area of Crushed Tuff}

The surface area of batches of crushed Tctb used in Waste Package experiments was determined. Both $A r$ and $N_{2}$ BET gas adsorption methods were used. The results are shown below:

$\begin{array}{lllll}\text { Tcfh-A } & \# \mathrm{l} & 5.07 & \mathrm{~m}^{2} / \mathrm{g} & (\mathrm{Ar}) \\ \text { Tefb-A } & \# 2 & 5.06 & \mathrm{~m}^{2} / \mathrm{g} & (\mathrm{Ar}) \\ \text { Tifl-A } & \# 3 & 0.25 & \mathrm{~m}^{2} / \mathrm{g} & \left(\mathrm{N}_{2}\right)\end{array}$

$\begin{array}{lllll}\text { Tcfb-B } & \# 1 & 3.83 & \mathrm{~m}^{2} / \mathrm{g} & \text { (Ar) } \\ \mathrm{Tcfb}-\mathrm{B} & \# 2 & 3.79 & \mathrm{~m}^{2} / \mathrm{g} & (\mathrm{Ar}) \\ \text { Tcfb-B } & \# 3 & 4.79 & \mathrm{~m}^{2} / \mathrm{g} & \left(\mathrm{N}_{2}\right)\end{array}$

The results are quite consisterit with $N_{2}$ surface areas about $20 \%$ higher than $\mathrm{Ar}$, which is usually the case. The two baiches prepared do have distinctly different specific surface areas with Batch B about $25 \%$ lower than biatch $A$.

\section{Analytical Mineralogy}

There are seversl reasons why it is necessary to know both the whole rock geochemistry and tha' mineralogy and individual phase chemistry of rock used in waste package experiments. Warren and co-workers at 1. NI. (Bish et al., 1931) have shown the potential for using phenocryst geothemistry to define/distinguish/correlate tuff formations or menubers and to recognize relative position within eruptive units. The waste package aqueous environment atter waste emplacement will be determined by complex interactions involving dissolution/precipitation kinetics and thermodynamic equilibrium. These interictions are a function of the individual phase chemistry of the tuff rather than the whole rock genchemistry. Finally, to fully understand the sources and sinks for disiolved species (mass balance), one must consider more than just the evolution of the aquecus phase in hydrothermal rock/water interaction experiments.

To geochemically characterize the individual phases in Tofb, both the polished thin section and a polished core water were examined by SEM and analyed by qualitative EDS and quantitative WDS with an automated electron microprobe (EMP). The JEOL 733 Superprobe was typically operaled (for EDS and WDS) at a $15-\mathrm{kV}$ accelerating potential, a $15-\mathrm{nA}$ (or less) beam current, and a $100-\mu^{2}$ rastered heam smaller beam areas were used with correspondingly lower beam current where required. To minimize volatile loss, $\mathrm{Na}$ and $K$ were always counted first in the automated schedule of analyes. Elements were calibrated against appropriate well-characterized silicate standards provided ly Charles Taylor, Co., Palo Alto, CA. Oxide weight percentages reported in
Table 3 were calculated with a Bence-Albee correction scheme.

The results of quantitative ENP analyses are listed in Table 3 and grouped by phase. Note that pumice or matrix data are analyses of a mixture of phases, i.e., quartz and alkali feldspar, on a micron to submicron scale. Phenocrysts were analyzed at their cores, uilless otherwise noted.

As shown by Warren (Bish et al., 1981). the dominant value and range of the most important compositional components are frequently invariant for a single ash-fiow sequence and can be recognized in histograms. They are thus correlative tools for these units. Altrmatively, similarities among mineral compositions between units may define petrographic suites. Histograms were made to show variation in polassium (orthoclase molecular end member, Fig. 14) in alkali feldspar, calcium variation (anorthite molecular end nember. Fig. 15) in plagioclase, and magnesium/iron variation $(\mathrm{Mg} / \mathrm{Mg}+\mathrm{Fe}$ ) in both biotite (Fig. 16) and amphibole (Fig. 17). Note that nore samples are plotted than tabulated in this report, because only thin-section data were tabulated here. The tabulated data for the reference Tctb corc wafer are presented in another report (Knauss, 1983). The histogram, however, contains data from both sources, although individual histogra!ns of thinsection vs core wafer are indistinguishable and are combined simply to improve siatistics. Although quartz, magnetite, ilmenite, zircon, and apatite were also observed in thin-section, no analyses are presented here. A fess analvices for these phases are included in the Tcfh cors wafer report mentioned above. 
Table 3. Results of quantitative electron microprobe analyses using wavelength dispersive methods and Bence-Albee data reduction schemes. Analytical conditions used on the fully automated system are detailed in the text.

Table 3a. Biotite.

\begin{tabular}{|c|c|c|c|c|c|c|c|c|c|c|c|c|}
\hline Oxide & 1.1 & 1.2 & 1.3 & 1.4 & 2.1 & 2.2 & 2.3 & 2.4 & 4.1 & 4.2 & 4.3 & $4.4^{2}$ \\
\hline $\mathrm{SiO}_{2}$ & 36.30 & 35.43 & 35.56 & 35.55 & 37.38 & 37.24 & 37.43 & 37.79 & 36.24 & 35.22 & 36.92 & 37.09 \\
\hline $\mathrm{Al}_{2} \mathrm{O}_{3}$ & 13.96 & 14.31 & 13.25 & 14.39 & 16.08 & 15.49 & 15.63 & 15.80 & 13.97 & 13.92 & 14.44 & 13.48 \\
\hline $\mathrm{K}_{2} \mathrm{O}$ & 8.76 & 8.72 & 8.87 & 9.14 & 8.40 & 8.30 & 8.55 & 8.54 & 8.55 & 8.73 & 8.71 & 9.07 \\
\hline $\mathrm{Na}_{2} \mathrm{O}$ & 0.56 & 0.54 & 0.51 & 0.52 & 0.78 & 0.83 & 0.79 & 0.79 & 0.57 & 1.55 & 0.52 & 0.55 \\
\hline $\mathrm{CaO}$ & $0.0 n$ & 0.03 & 0.04 & 0.00 & 0.02 & 0.02 & 0.03 & 0.04 & 0.02 & 0.00 & 0.05 & 0.02 \\
\hline $\mathrm{MgO}$ & 10.61 & 8.78 & 8.55 & 9.60 & 14.85 & 15.01 & 14.59 & 14.35 & 9.16 & 9.24 & 8.98 & 9.04 \\
\hline $\operatorname{MnO}$ & - & - & 0.31 & 0.81 & - & - & - & 0.40 & - & - & - & 0.84 \\
\hline $\mathrm{TiO}_{2}$ & 4.40 & 4.43 & 4.36 & 4.33 & 4.52 & 4.42 & 4.50 & 4.66 & 3.85 & 4.52 & 4.62 & 4.54 \\
\hline : & - & - & 0.05 & 0.00 & - & - & - & 0.00 & - & - & - & 0.12 \\
\hline $\mathrm{Cl}$ & - & - & 2.22 & 1.85 & - & - & - & 0.72 & - & - & - & 1.82 \\
\hline
\end{tabular}

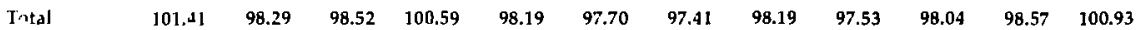

$\begin{array}{lllllllllllll}\text { Ti/fe } & 0.152 & 0.160 & 0.158 & 0.160 & 0.273 & 0.265 & 0.272 & 0.278 & 0.139 & 0.166 & 0.172 & 0.168\end{array}$

\begin{tabular}{lllllllllllll}
$\mathrm{Mg} / \mathrm{Mg}+\mathrm{Fe}$ & 0.422 & 0.388 & 0.383 & $\mathbf{0 . 4 1 5}$ & $\mathbf{0 . 6 4 2}$ & $\mathbf{0 . 6 4 3}$ & 0.638 & $\mathbf{0 . 6 3 1}$ & $\mathbf{0 . 3 9 8}$ & 0.405 & 0.401 & 0.400 \\
\hline
\end{tabular}

\begin{tabular}{|c|c|c|c|c|c|c|c|c|c|c|c|}
\hline Oxide & 9.1 & 9.2 & 9.3 & 70.1 & 10.2 & 10.3 & 10.4 & 12.1 & 12.2 & 12.3 & $12.4^{4}$ \\
\hline $\mathrm{SiO}_{2}$ & 36.65 & 36.77 & 36.08 & 35.85 & 36.07 & 36.75 & 37.02 & 35.62 & 34.42 & 35.75 & 33.37 \\
\hline $\mathrm{A} !, \mathrm{O}_{3}$ & 14.36 & 13.56 & 13.43 & 14.05 & 14.38 & 13.29 & 13.54 & 14.47 & 14.74 & 13.82 & 16.94 \\
\hline$h_{2} \mathrm{O}$ & 8.63 & 8.44 & 8.74 & 8.59 & 8.62 & 8.60 & 8.70 & 8.52 & 8.38 & 8.02 & 8.50 \\
\hline $\mathrm{Na}_{\mathbf{O}} \mathrm{O}$ & 0.53 & 0.48 & 0.54 & 0.60 & 0.56 & 0.50 & 0.55 & 0.49 & $0.5 t$ & 0.54 & 0.45 \\
\hline $\mathrm{CaO}$ & 0.01 & 0.00 & 0.00 & 0.00 & 0.00 & 0.00 & 0.07 & 0.00 & 0.00 & 0.00 & 0.11 \\
\hline leo & 25.37 & 24.18 & 24.68 & 25.10 & 25.16 & $\approx 4.27$ & 24.73 & 25.47 & 25.39 & 25.22 & 24.72 \\
\hline $\mathrm{MgO}$ & 6.55 & 8.75 & 8.48 & 8.59 & 8.69 & 8.52 & 8.57 & 7.78 & 8.42 & 9.05 & 7.91 \\
\hline $\mathrm{MnO}$ & - & - & 0.78 & - & - & - & 0.80 & - & - & - & 0.79 \\
\hline $\mathrm{IjO}=$ & 4.32 & 4.91 & 4.95 & 4.40 & .27 & 4.63 & 4.82 & 4.14 & 4.71 & 4.64 & $4 .$. \\
\hline 1 & - & - & 0.00 & - & - & - & 0.00 & - & - & - & 0.00 \\
\hline $\mathrm{Cl}$ & - & - & 1.66 & - & - & - & 1.54 & - & - & - & 1.86 \\
\hline Total & 99.40 & 97.99 & 97.36 & 98.68 & 59.29 & 97.60 & 100.33 & 98.07 & 98.08 & 98.39 & 99.51 \\
\hline $\mathrm{Ti} / \mathrm{Fe}$ & 0.153 & 0.183 & 0.181 & 0.158 & U. 153 & 0.172 & 0.175 & 0.146 & 0.167 & 0.166 & 0.177 \\
\hline $\mathbf{M g}_{g} / \mathbf{M}_{g}+\mathrm{Ke}$ & 0.377 & 0.394 & 9.382 & 0.351 & 0.383 & 0.387 & 0.384 & 0.355 & 0.374 & 0.392 & 0.366 \\
\hline Oxide & 15.1 & & 15.2 & 15.3 & 18.1 & & 18.2 & 28.3 & & .1 & $20.2^{\mathrm{N}}$ \\
\hline $\mathrm{SiO}$ & 35.70 & & 35.64 & $3+.43$ & 37.22 & & $35.8 \%$ & 36.77 & & & 36.67 \\
\hline $\mathrm{Al}_{2} \mathrm{O}_{3}$ & 13.90 & & 13.74 & 14.05 & 14.25 & & $: 4.52$ & 13.38 & & & 13.17 \\
\hline $\mathrm{K}_{2} \mathrm{O}$ & 8.37 & & 7.99 & 8.72 & 9.07 & & 8.84 & 8.95 & & 73 & 8.83 \\
\hline $\mathrm{Na}, \mathrm{O}$ & 0.54 & & 0.66 & 0.53 & 0.61 & & 1.40 & 0.55 & & 52 & 1.28 \\
\hline $\mathrm{CaO}$ & 0.09 & & 0.08 & 0.04 & 0.00 & & 0.02 & 0.83 & & 00 & 0.03 \\
\hline leo & 24.35 & & 24.80 & 24.75 & 23.55 & & 23.26 & 22.79 & & & 22.96 \\
\hline $\operatorname{IgO} O$ & 8.39 & & 8.66 & 8.36 & 9.98 & & 9.78 & 9.96 & & & 8.99 \\
\hline $\mathrm{MnO}$ & - & & - & 0.80 & - & & - & 0.73 & & - & - \\
\hline $1,0=$ & 4.62 & & 4.50 & 4.63 & 4.14 & & 4.51 & 4.60 & & 20 & 4.15 \\
\hline$F$ & - & & - & 0.00 & - & & - & 1.48 & & - & - \\
\hline , & - & & - & 1.76 & - & & - & 1.68 & & - & - \\
\hline$\theta_{i \cdot t}$ & 97.21 & & 96.72 & 98.07 & 98.74 & & 98.00 & 100.94 & & & 96.07 \\
\hline$\quad \therefore$ & 0.171 & & 0.163 & 0.168 & 0.154 & & 0.175 & 0.182 & & 156 & 0.163 \\
\hline$A$ W. $\quad f$ & 0.383 & & 0.369 & 0.378 & 0.433 & & 0.431 & 0.440 & & 427 & 0.413 \\
\hline
\end{tabular}


Table 3b. Hornblende.

\begin{tabular}{|c|c|c|c|c|c|c|c|}
\hline Oxide & 5.1 & 8.1 & 13.1 & 13.2 & 13.3 & 19.1 & $19.2^{4}$ \\
\hline $\mathrm{SiO}_{2}$ & +2.78 & 43.13 & 45.61 & 45.73 & +6.72 & 43.70 & 44.34 \\
\hline $\mathrm{Al}_{2} \mathrm{O}_{3}$ & 12.16 & 9.43 & 7.01 & 6.94 & 6.59 & 7.59 & 7.48 \\
\hline $\mathrm{K}_{2} \mathrm{O}$ & 0.60 & 0.81 & 0.70 & 0.53 & 0.58 & 0.75 & J.69 \\
\hline $\mathrm{Na}_{2} \mathrm{O}$ & 2.12 & 1.93 & 1.81 & 1.76 & 1.79 & 1.82 & 1.77 \\
\hline $\mathrm{CaO}$ & 11.05 & 10.49 & 9.74 & 10.07 & 10.04 & 9.65 & 9.30 \\
\hline $\mathrm{reO}$ & 12.35 & 20.92 & 22.09 & 21.50 & 21.00 & 21.68 & 20.76 \\
\hline $\mathrm{TiO}$ & 2.17 & 1.69 & 1.17 & 1.28 & 1.41 & 1.41 & 1.46 \\
\hline $\mathrm{MgO}$ & 13.25 & 8.73 & 9,51 & 9.20 & 9.02 & 8.63 & 8.52 \\
\hline $\mathrm{MnO}$ & 0.32 & 1.48 & 1.35 & 1.75 & 1.65 & 1.72 & 1.52 \\
\hline F & 0.00 & 0.00 & 0.00 & 0.07 & 0.00 & 0.00 & 0.05 \\
\hline $\mathrm{Cl}$ & 0.00 & 0.00 & 0.00 & 0.00 & 0.00 & 0.00 & 0.00 \\
\hline Total & 46.80 & 48.62 & 98.99 & 98.85 & 98.83 & 96.94 & 95.90 \\
\hline $\begin{array}{l}\text { Ti/le } \\
M g / M g\end{array}$ & 0.158 & 0.073 & $0.0+8$ & 0.054 & 0.061 & 0.058 & 0.063 \\
\hline. $\mathrm{Fe}$ & 0.659 & 0.429 & 0.437 & 0.435 & 0.436 & 0.417 & 0.425 \\
\hline
\end{tabular}

Table 3c. Matrix.

\begin{tabular}{lrrrrrr}
\hline Oxide & 4.1 & 4.2 & 10.1 & 16.1 & 16.2 & $18.1^{2}$ \\
\hline $\mathrm{SiO}_{2}$ & 76.41 & 80.15 & 77.37 & 85.65 & 70.94 & 74.75 \\
$\mathrm{Al}_{2} \mathrm{O}_{3}$ & 15.14 & 12.70 & 12.06 & 6.50 & 15.71 & 13.32 \\
$\mathrm{~K}_{2} \mathrm{O}$ & 4.31 & 1.16 & 4.42 & 3.66 & 8.79 & 7.17 \\
$\mathrm{Na}_{2} \mathrm{O}$ & 3.91 & 3.68 & 3.10 & 1.07 & 2.62 & 2.76 \\
$\mathrm{CaO}$ & 0.80 & 1.03 & 0.39 & 0.10 & 0.29 & 0.31 \\
$\mathrm{MgO}$ & 0.05 & 0.02 & 0.03 & 0.06 & 0.06 & 0.00 \\
$\mathrm{FeO}$ & 0.19 & 0.38 & 0.60 & 0.44 & 0.94 & 0.25 \\
$\mathrm{TiO} \mathrm{Z}_{2}$ & 0.22 & 0.06 & 0.04 & 0.00 & 0.14 & 0.25 \\
$\mathrm{MnO}$ & 0.00 & - & 0.04 & - & 0.08 & 0.00 \\
$\mathrm{BaO}$ & 0.00 & 0.00 & 0.00 & 0.19 & 0.00 & 0.00 \\
$\mathrm{Total}$ & 101.19 & 49.14 & 98.16 & 48.17 & 99.68 & 48.87 \\
$\mathrm{Qz}$ & 33.75 & - & 40.52 & - & 211.06 & 24.22 \\
$\mathrm{Or}$ & 26.17 & - & 27.82 & - & 54.14 & 43.64 \\
$\mathrm{Ab}$ & 36.03 & - & 24.61 & - & 24.50 & 25.49 \\
$\mathrm{An}$ & 4.05 & - & 2.06 & - & 1.25 & 1.34 \\
\hline
\end{tabular}

Table 3d. Plagioclasc.

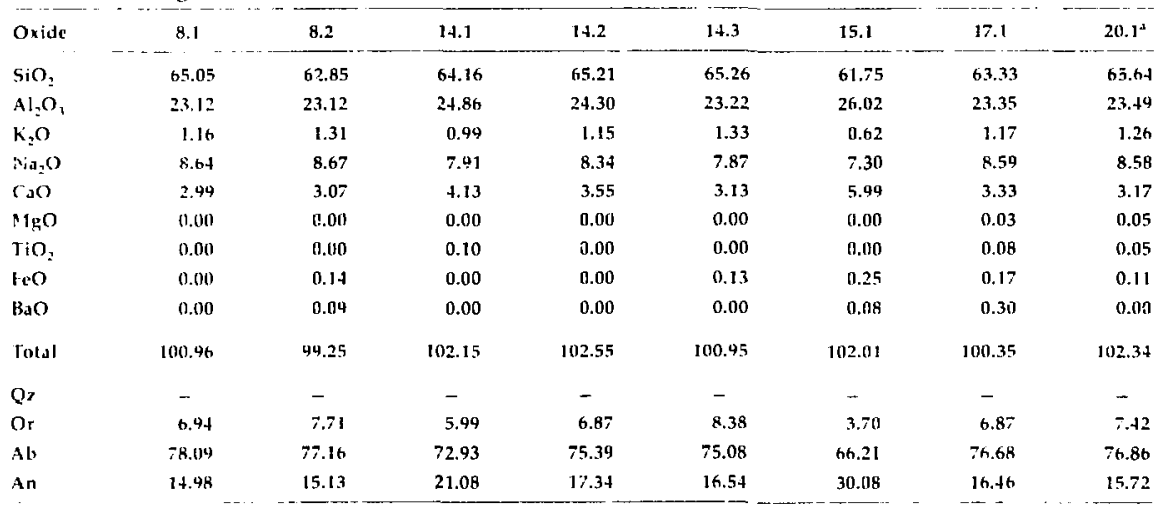

Table 3e. Sanidine.

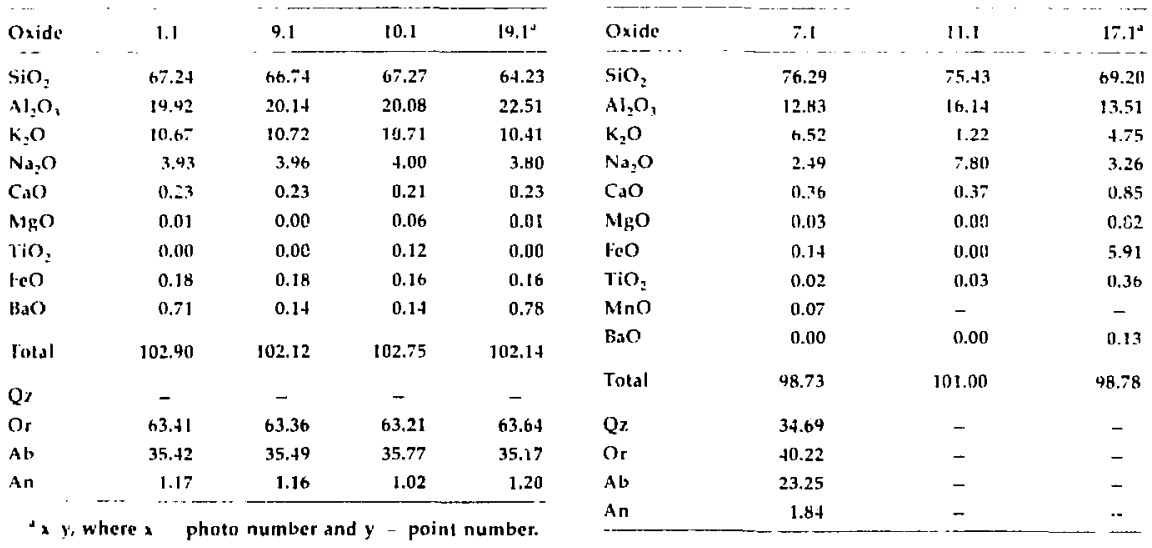

Table 3f. Pumice. 


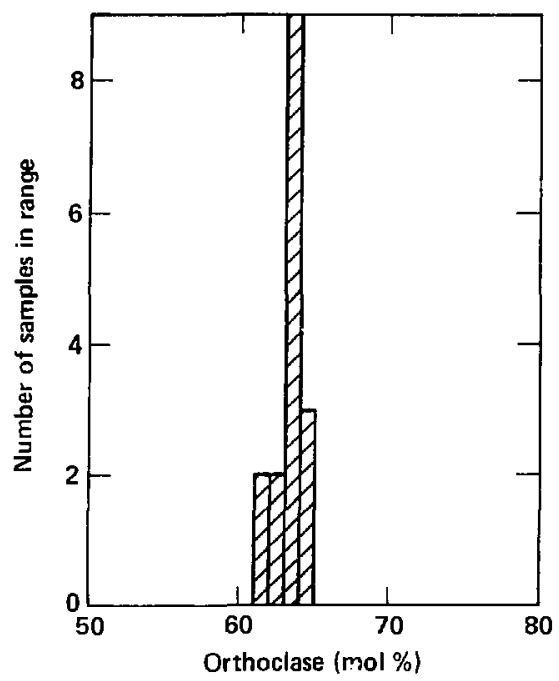

Figure 14a. Ordinary histogram of cation norinative orthoclase calculated for analyzed alkali feldspar phenocrysts. The average value is about 0.63 OR.

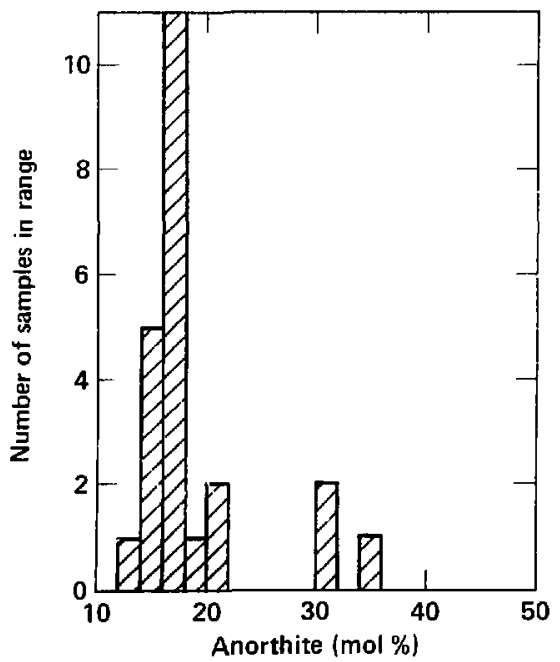

Figure 15a. Ordinary histogram of cation normative anorthite calculated for analyzed plagioclase feldspar phenocrysts. The most common value is $0.17 \mathrm{AN}$.

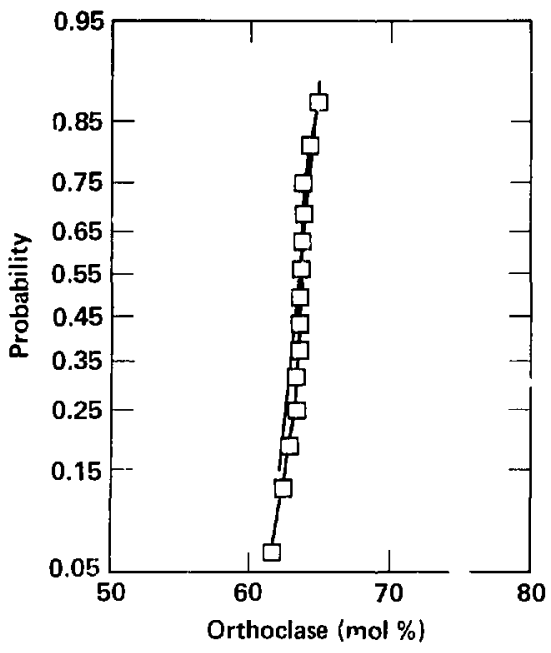

Figure 14b. Cumulative frequency plot of data presented in Fig. 14a showing presence of only one population.

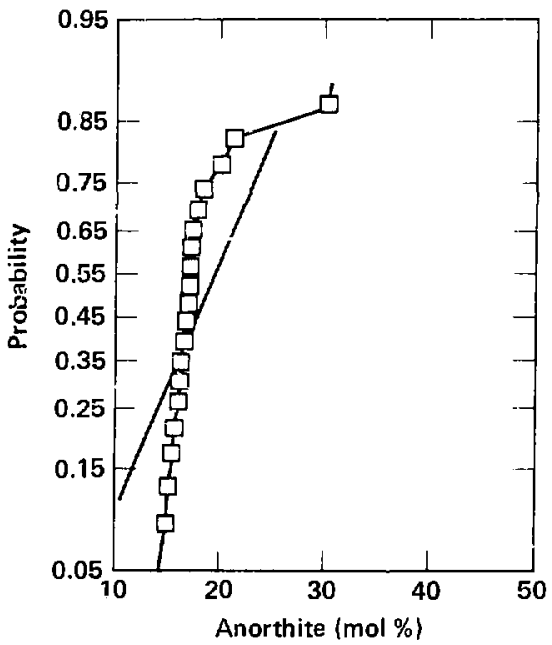

Figure 15b. Cumulative frequency plot of data presented in Fig. 15a showing a distinctly bimodal distribution. 


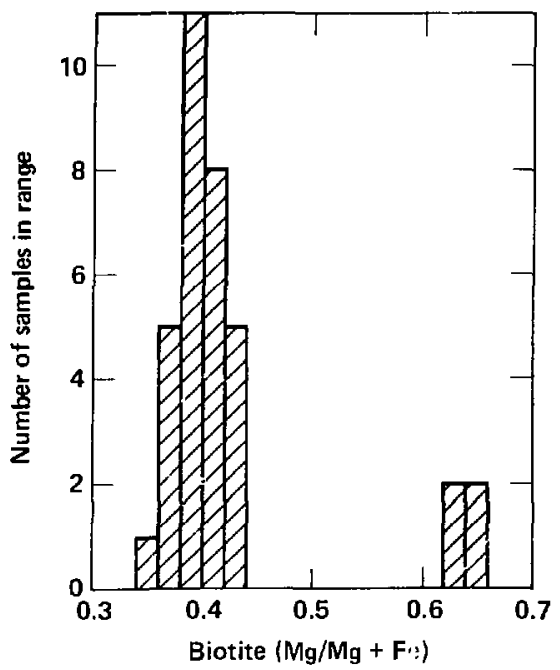

Figure 16a: Ordinary histogram of cation ratio calculated for analyzed biotite phenocrysts. The most common value for this ratio is about 0.4.

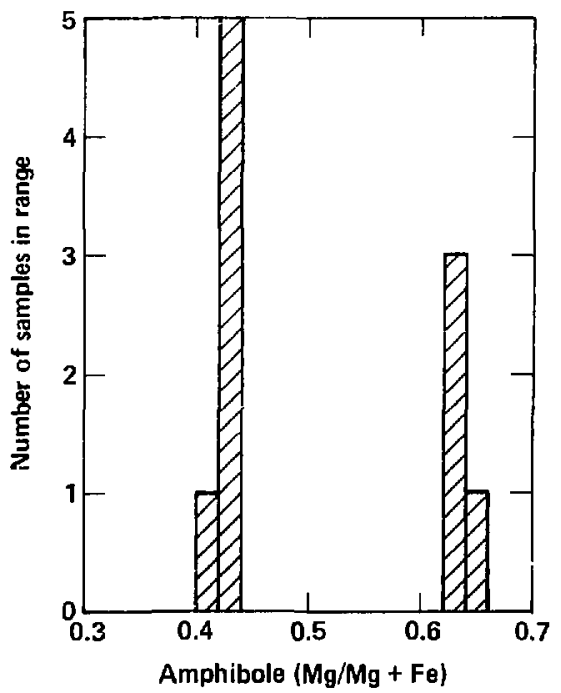

Figure 17a, Ordinary histogram of cation ratio calculated for ana', ' d hornblende phenocrysts. The most common value is also about 0.4.

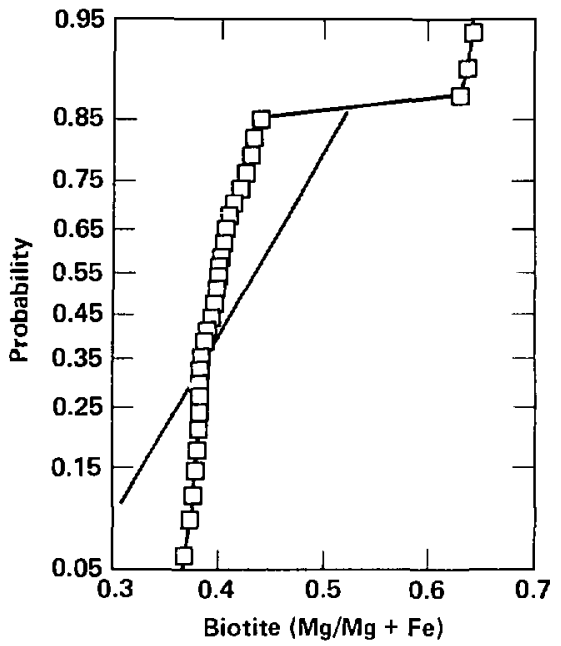

Figure 16b. Cumulative frequency plot of data presented in Fig. 16a showing a distinctly bimodal distribution with one group at 0.4 and a second at 0.6 .

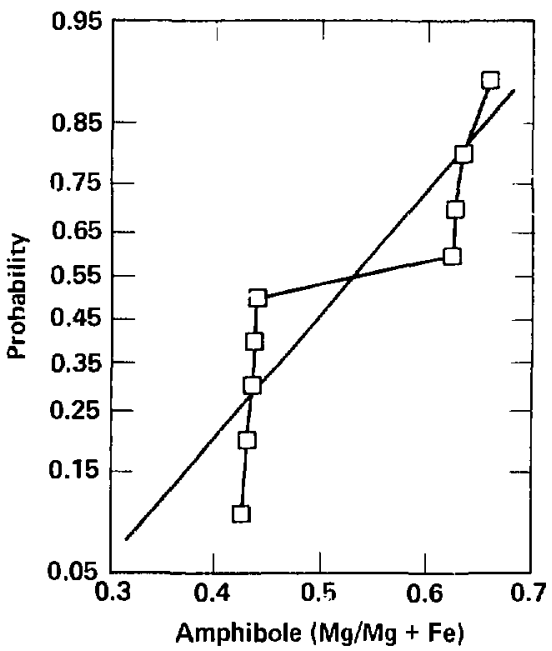

Figure 17b. Cumulative frequency plot of data from Fig. 17a showing a distinctly bimodal distribution with one group at 0.4 and another at 0.6 . 
The average orthoclase end member content for the alkali feldspar is $63 \mathrm{~mol} \%$ and the distribution is normal. The range in observed values is very small, varying from $61-65 \mathrm{~mol} \%$. The dominant anorthite end member content of the plagioclase is $17 \mathrm{~mol} \%$ with an average of $18.6 \mathrm{~mol} \%$, while the distribution is bimodal. Some of the normally zoned plagioclase cores were distinctly Ca rich, ranging up to $36 \mathrm{~mol} \%$. The lower limit of observed anorthite end member composition was about $12 \mathrm{~mol} \%$. The mafic phenocrysts, biotite and hornblende, were relatively $\mathrm{Mg}$ poor. For both mafics the dominant $\mathrm{Mg} /(\mathrm{Mg}+\mathrm{Fe})$ ratio was 0.4 , although the distribution was distinctly bimodal with a second group at 0.64 .

The histograms for feldspar end members presented here for Tcfb outcrop samples are virtually identical to those presented by Warren (Bish et al., 1981) for hole G.1. The mafic $\mathrm{Mg} /(\mathrm{Mg}+$ $\mathrm{Fe}$ ) ratio differs, however, in that the 0.4 population ohserved by Warren at Yucca Mountain in $\mathrm{G}-1$ is accompanied by a distinct group at 0.6 . This high $\mathrm{Mg}$ hornblende was also observed by Warren (unpublished data, 1982) in samples from the same Lathrop Wells Tcfb section in specimens collected from the vitrophyre. Single mafic phenocrysts produce analyses clearly in only one of the two groups. The $\mathrm{Mg}$-rich mafics are significantly less common than the Fe-rich mafics and are not contained within lithic fragments. Although not plotted here, the EMP data in Table 3 show the average trotite $\mathrm{BaO}$ weight percent to be about $0.6 \%$, with a dominant value somewhat lower. Warren observed that in the Tcfb, the upper portion of the unit tended to have a higher $\mathrm{BaO}$ content $(1.3 \%)$ compared to the lower portion $(0.3 \%)$.

\section{Summary}

The purpose of this characterization of Tcfb is twofold: first, to provide data about the mineralogy and chenistry of the rock used in experiments utuporting wiste package design (geochemical modeling and corrosion, radiation damage, thermunechanical studies, etc.) and second, to verify that the autcrop material used to provide large quantitie of rock for the experimental prograin matched reasonably well with the rock at depth beneath rucia Mountain within the proposed Tith repository interval.

The bacii data provided here include the f.llowirg:

- Simple petrographic description.

- Relative distritiution of the dominant phase's.

- XRD analyses and phase identification.

- SLA phase identification.

- Nalure and distribution of fractures and fillings.

- BET surface area analyses.

- NAA chemical analyses of whole rock.

- EMP yuantitative chemical analyses of phase's.

Field relationships suggest that the outcrop material is stratigraphically equivalent to the densely welded, devitrified, vapor-phase altered core of the BF-ll subunit within the Tcfb. The material contains no zeolites and appears to be glassfree. It does, however, contain trace amounts of evapoite minerals (carbonates, borates, sulfates, nitrates, etc.) due to precipitation from meteoric waters (Oversby and Knauss, 1983). The mineralogy and nature of devitrification and vapor phase alteration products would also suggest that the material most closely matches the BF-Il subunit above th. 2400-ft depth (relative to G-1) and within the $\mathrm{Tcfb}$ intelval considered suitable host rock for a repository. The $\mathrm{BaO}$ content of the biotites suggests the samples are from the lower rather than the upper portions of the Bullfrog Member Tuff. These outcrop samples should be acceptable representatives of the $\mathrm{TcFb}$ unit beneath Yucca Mountain for experiments performed in support of Waste Package design.

The Bullfrog Member of the Crater Flat tuff is one of four YLicca Mountain tuff units that were under consideration by the Nevada Nuclear Waste Storage investigations (NNWS1) Project as a potential location for a mined geologic repository for high-level nuclear waste. Two of the units, the Topopat, Spring Member of the Paintlrush tuff and the tuffaceous beds of the Calico Hills, are located above the water table in the unsaturated zone. The other units, the Bullfrog and Tram, are located below the water table. The NNW'SI Project chose the Topopah Spring Member of the Painthrush tuff as the reference reposilory horizon in mid-1982. Data generated using Tofb rock/water interaction studies are still quite useful, indeed required, for establishing the ability of the EQ3/6 geochemical modeling code to match (predict after-the-fact) experimental results. Some degree of confidence can then be placed on the use of the code for predicting conditions over the long-term for geologic units with similar mineralogy and geochemistry. 


\section{Acknowledgments}

Many thanks to the following individuals, and others not specifically men: oned, for their invaluable contributions to this project. Bill Beiriger ran the XRD scans and prepared the polished thin sections and core wafers. Jan Brown did NAA sample preparation, and Bob Heft performed the irradiation, gamma analyses, and data reduction. Chuck Slettevold made the BET analyses. Bruce Crowe spent a day in the field with me and introduced me to the Tcfb section at Lathrop Wells. Rich Warren providea unpublished micropube analyses of related samples from this section and suggested other locations for material. Rick Ryerson helped me nver many pitfalls encountered during EMP analyses. He provided direct assistarie and moral support, gratis. Thanks to Barbara Bryan for expert typing.

\section{References}

Bish, D. L., F. A. Caporuscio, J. F. Copp, B. M. Crowe, J. D. Purson, J. R. Smyth, and R. G. Warren (1981),

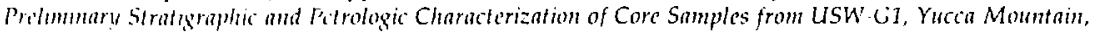
Siriliti, Los Alamos National laboratory, Los Alamos, NM, LA-8840-MS.

Broxton, D., D. Vaniman, F. Caporuscio, B. Arney, and G. Heiken (1982), Detailed Pelrographic Descriptions and Maruprebe Dala tor Drill Holes USW-G2 and UE25b-1H. Yucca Motmtain, Newada, Los Alamos National Laborators, Los Alamos, NM, LA-9324-MS.

Byers, F. M., W. J. Carr, P. P. Orkild, W. D. Quinlivan, and K. A. Sargent (1976), Volcami Suites and Related Cauldrmo of Tumber Monutain-Casis Valley Caldera Complex, Southern Nezada, U.S. Geological Survey, Menlo Park, CA, Prof. Paper 919, 70 pp.

Caporuscio, F., D. Vaniman, D. Bish D. Broxton, B. Arney, G. Heiken, F. Byers, R. Gouley, and.E. Srmarge (1982), Pitrolege situtics of Drit Cores UISW-G2 and LIE25b-1H. Yucci Mnumin, Niziata, Los Alamos National Laboratory, l.os Alamos, NM, LA-9255-MS.

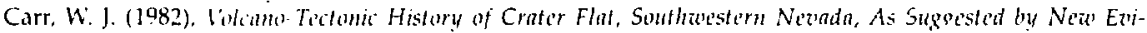
donce trom Mrill Hoh USW-l'H-7 and Vicinity. U.S. Geological Survey, Menlo Fark, CA, Open File Report 82-457, $23 \mathrm{pp}$.

Heiken, G. H., and M. I. Bevier (1979), Fitrology of Tuff Units from the 1-1.3 Drill Site, Jackass Flats, Nevada, Los Alamos National Laboratory, Los Alamos, NM, I.A-7563-MS.

Knauss. K. (;. (1983), Wydrothermal Inleration Studies of Bullfrog Tuff Cor ${ }^{\circ}$ Wafers in $/-13$ Waler at $150^{\circ} \mathrm{C}-$ Qumtitaln' Anulys:s of Aquens and Solid Phases, Lawrence Livermore National Laboratory, Livermore, CA, UCRI. Report in progress.

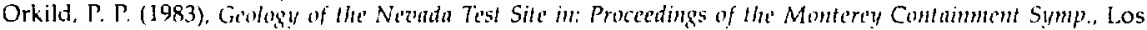
Alamos National Laboratory, Los Alamos, NM, LA-9211-C, vol. 1, pp. 323-338.

Overshy, V. M., and K. G. Knauss (1983), Reuclion of Bullfrog Tulf aill, $\left[-73\right.$ Woll Water at $9 f^{\circ} \mathrm{C}$ and $1.50^{\circ} \mathrm{C}$. Law'rence I.ivermore National Laboratory, Livermore, CA, UCRL-53442.

Scott, R., and M. Castellanos (1982), Prelimimary Report On the Geologic Character of Drill Hold's LISW-GLI.3 and LISW'G.3, U.S. Geological Survey, Menlo Park, CA, Memorandum Report.

Sykes, M. L., G. H. Heiken, and J. R. Smyth (1979), Mineralogy and Petrology of Tuff Lnits from the UE25a-1 I rill Sitti, Yucia Monutim, Netada, Los Alamos National Laboratory, Los Alamos, NM, LA-8139-MS. 